vations of the convective boundary layer. J. Appl. Meteor., 16, 1306-1311.

RAF, 1981: Queen Air: Overview and summary of capabilities. NCAR Res. Aviat. Facil. (RAF) Bull. 2, NCAR, Boulder, Colo., 10 pp. (Available from NCAR, P.O. Box 3000, Boulder, CO 80307.)

Sroga, J. T., E. W. Eloranta, and T. Barber, 1980: Lidar measurement of wind velocity profiles in the boundary layer. J. Appl. Meteor., 19, 598-605.

Stull, R., 1983a: Boundary Layer Experiment-1983 (BLX83) Opera- tions Log and Data Inventory. Meteorology Department, University of Wisconsin, Madison, Wis., 72 pp. (Available from the Meteorology Department, University of Wisconsin, 1225 W. Dayton St., Madison, WI 53706.)

- 1983b: Boundary Layer Experiment-1983 (BLX83) Scientist's Flight Log. Meteorology Department, University of Wisconsin, Madison, Wis., 100 pp. (Available from the Meteorology Department, University of Wisconsin, 1225 W. Dayton St., Madison, WI 53706.)

\title{
announcements'
}

\section{Satellite workshop}

The Wisconsin Meteorological Satellite Workshop (WMSW) will be held at the Space Science and Engineering Center (SSEC) at the University of Wisconsin-Madison from 16 July to 3 August 1984. It is intended to offer meteorologists a hands-on experience with the latest advances in satellite meteorology, and is being sponsored by the Cooperative Institute for Meteorological and Satellite Studies (CIMSS).

Enrollment in the workshop is limited and priority will be given to non-U.S. scientists who do not have a strong background in satellite meteorology and to participants who enroll for the entire three-week program. Instructors will be personnel from SSEC, the National Environmental Satellite Data and Information Service (NESDIS), and from other selected institutions as expertise dictates. All technical sessions will be held at the Meteorology and Space Science Building at the University of Wisconsin-Madison.

The workshop will be set up in modular format with each of the one-week modules being self-contained, as follows: 1) The Basics (16-20 July); 2) Satellite Data-A Survey (23-27 July); and 3) Satellite Data-Applications (30 July-3 August).

The fee for this workshop is $\$ 500$ for the entire three-week session, or $\$ 250 /$ week for individual weeks. The fee does not include housing or food service, which will be available at University dormitories at extra cost. For additional information, contact David Suchman, Space Science \& Engineering Center, University of Wisconsin-Madison, 1225West Dayton Street, Madison, WI53706 (tel.: 608-262-5772).

${ }^{1}$ Notice of registration deadlines for meetings, workshops, and seminars, deadlines for submittal of abstracts or papers to be presented at meetings, and deadlines for grants, proposals, awards, nominations, and fellowships must be received at least three months before deadline dates.-News Ed.

\section{University of Michigan announces two summer conferences}

Two summer engineering conferences are scheduled for June 1984 at the University of Michigan. "Infrared Technology: Fundamental and System Applications," will be held 18-22 June, and covers radiation theory, radiative properties of matter, atmospheric propagation, optics, and detectors. It also emphasizes system design and the interpretation of target and background signals. The "Advanced Infrared Technology" conference, 25-29 June, presents the advanced technology needed for modern, state-of-theart, active/passive infrared and optical systems. Presentations cover atmospheric propagation, detectors and focal plane array technology, discrimination characteristics of targets and backgrounds, and system designs. Familiarity with fundamentals of infrared is a prerequisite. For more information, contact Viola E. Miller, Engineering Summer Conferences, 200 Chrysler Center, North Campus, Ann Arbor, MI 48109 (tel.: 313-764-8490).

\section{Deadlines Calendar}

Fellowships, grants, etc.

15 June $1984 \quad$ Macelwane Annual Award (this issue, p. 471)

15 June $1984 \quad$ Hanks and Orville Scholarships (this issue, p. 471)

Other

13 August 1984 NCAR Research Aviation Facility panel meeting (April 1984 Bulletin, p. 400) 